\title{
APOPHONY IN THE VERBAL SYSTEM OF GADANG
}

\author{
Herrmann Jungraithmayr
}

\section{Introduction ${ }^{*}$}

Many Chadic verbal systems are based on the binary aspectual opposition between perfective and imperfective forms marked by vowel change, i.e., ablaut or apophony (Jungraithmayr 1997). (For a general discussion of the Chadic verbal system, see Schuh 1976.) Full fledged apophony is to be found in most far eastern Chadic languages (spoken in the Chad Republic), like Mokilko, Migama, Mubi, Dangaleat, and Sokoro (see Jungraithmayr 1978a, 1990). Most of the near eastern languages, e.g., Zime or Tumak (Caprile 1975), however, have transformed their ablaut systems into oppositions based on tone, i.e., abton or apotony, e.g.,

Far Eastern (e.g., Mubi)

'to drink' sû / súwáà

'to die'

măt / mùwáat
Near Eastern (e.g., Tumak)

hě / hè

má / mā

Compare, also, Masa (of Toura) ci'é / cíè 'to drink' and midá / mídà 'to die', in contrast to Mokilko 'íibè (subjunctive: síbè) / sóbò and 'ìndá / 'ûntó.

\footnotetext{
* The sample of 165 verbs on which the analysis in this article is based was recorded in March 1973. The work was part of my Chad project (1970-80) which was supported by the Deutsche Forschungsgemeinschaft. I wish to express my sincere gratitude to this institution for its invaluable support which enabled me to extend our research activities to the eastern branch of Chadic, which at that time had not yet received the scientific attention it deserved. Moreover, I would like to thank the members of the Catholic Church community in Bousso/Chari where I was kindly invited to live and to carry out my fieldwork. The language assistant and informant to whom I owe all my Gadang data was M. Kalamsa Djom, whom I wish to thank very much for his patience and interest in the process of recording his mother tongue.
} 
Those eastern branch languages, that are spoken between "far" and "near", i.e., mainly in the region between the Logone and Chari rivers ("Zweistromland"), generally display relatively weak apophonic opposition patterns, which is certainly due to a gradual reduction process in which the final stage is the replacement of the apophony strategies by those of apotony. Tumak, the southernmost language of this area, which may appropriately be called "Central Eastern", has already reached this stage-of pure apotony -, probably due to its geographic proximity to non-Chadic (Nilo-Saharan) languages which excel in apotony-based verbal systems (cf. Jungraithmayr 1980). It is this central zone within the eastern branch of Chadic to which Gadang, as a member of the Sumray group, belongs.

\section{Gadang}

Gadang (gàdàt) is one of the three riverain languages spoken along the river Chari near Bousso extending to the east and southeast of it, the other two languages being Sarwa and Miltu (Gali). The entire area has been under the domination of the Bagirmi kingdom, the headquarters of which was/is Massenya, which lies northwest of Bousso. Today Bousso is the administrative centre of the Préfécture du Chari-Baguirmi.

We owe the first information on the languages in question to the German traveller Gustav Nachtigal (1834-1885), who passed through this region in 1872 and collected a few data on Sarwa and Miltu (cf. Nachtigal, vol. II, 1881, p. 689; Ganslmayr \& Jungraithmayr 1977). As to Gadang, he only indicates the nameas "Gandang" - on the map accompanying his text. The only other source for the region is Gaudefroy-Demombynes (1907), who also presents very few lexical items for Sarwa and Miltu only. Thus, information on Gadang is presented in this paper for the first time.

The principal settlements or villages of the Gadang speaking people are-from west to east - the following: Taouan, Gadang Kiao, Djaména, Morio, Balo, Gadang, Gadang-Gougouri, Gadang Haddad Daudi and Madjoum. Bousso lies in the centre of the Gadang speaking area.

\section{The Binary Aspect System of Gadang}

\subsection{Vowels and Tones}

Gadang is a 7-vowel language comprising the basic 5 vowels $i, e, a, o, u$, plus 2 central vowels, high $\partial$ and low $\Lambda$. This is in full conformity with its immediate eastern neighbour, Sarwa, as well as with its southern relative, Sibine (Sumray). 
As to the tonal structure, Gadang distinguishes three level tones, high á, mid (a or ā) and low à, and three tonal glides, high-low (â, áà), high-mid (áā), and mid-high (aá or āâ).

Both vowels and tones are heavily involved in the formation of the verbal aspect stems. Ninety-three of the 165 verbs do not display ablaut, but distinguish their aspect stems by tone ("abton") and the appropriate suffixes. That is to say, only 72 , i.e., less than half of our sample, exhibit some sort of apophony.

As to the change of vowel quality, the general trend in the transition from the perfective to the imperfective stem is a change from a high and central quality $(i$, $u, \partial, \Lambda)$ to a low or half-low quality $(a, e, o)$, i.e., the direction high towards low. In addition, lengthening of the vowel $a(\rightarrow a a)$ or, instead, geminating of $\mathrm{C}_{2}$ in a few examples has also been observed. Note that the vowel affected by quality change is $\mathrm{V}_{1}$ in biradical stems and $\mathrm{V}_{2}$ in triradical stems.

On the other hand, tonal patterns display the opposite movement from lower to higher, i.e., if the perfective stem has low tone, the imperfective tone is generally mid, and if the perfective stem is mid, the imperfective stem will be high.

\subsection{The Formation of the Aspect Stems}

3.2.1. The formation of the perfective stem (PST). The PST is made up of the verbal base with an aspect-sensitive vowel $\left(\mathrm{V}_{1}\right.$ or $\mathrm{V}_{1}$ plus $\left.\mathrm{V}_{2}\right)$ and the suffix $-g \Lambda$, which carries a mid or a low tone, copying the tone of the base to which it is suffixed; e.g., mìr-g $\bar{\Lambda}$ '(have) died', 'ùsùn-gì '(have) known'.

3.2.2. The formation of the imperfective stem (IPST). The IPST is formed by a base the vowel of which is, depending on the verbal class the verb belongs to, either identical with the vowel of the PST or apophonically derived from it. This base is almost always augmented by a suffix which is generally - $a$ or - $a a$; it is, however, dropped in front of an object, e.g., níyà sē náàm 'I am drinking water'.

3.2.3. Presentation of the verb stem bases. The two aspect stems are composed of the verb base and a suffix, i.e., in the PST - $g \Lambda$ and in the IPST $-a /-a a$. Since this paper concentrates on the verb bases and their modification, there is no need to repeat a citation of those suffixes. With regard to the tonal behaviour and the length of these morphemes, it should, however, be noted that the tone of - $g_{\Lambda}$ is a copy of that of the PST base, whereas tone and length of the IPST -a/-aa vary considerably obviously depending on the phonotonological shape of the verb base. For example: 


\section{PST}

'to break'

'to envelop'

'to suck' bìy-gì

lìgə̄r $-\mathrm{g} \bar{\Lambda}$

lāām-ḡ̄
IPST

bāy-āá

lígár-ā

láam-à

3.3. The Verbal Classes (VCs) According to the Apophonic Relationship between PST and IPST

There are "weak" verbs with no vowel quality or quantity change(s) between the two aspect stems (PST and IPST), and "strong" verbs with vowel quality and/or quantity change(s). Accordingly, the following VCs may be established.

3.3.1. "Weak" verbs. "Weak" verbs display no vowel change but tone change (low to mid or mid to high).

(W1) The a/a class

'to eat'

'to stand up'

'to suck'

'to lick'

'to hasten'

'to return'

'to fall'

'to walk'

'to turn'

'to run'

'to transform oneself'

'to think' (Ar.)

'to fear'

'to pray' (Ar.)

'to choose'

'to fry'

'to sweep'

'to exchange'
PST

yā-

sàa-

laam-

lagany-

nar-

dayn-

nas-

cà-

càr-

wày-

sar-

pagar-

laany-

sal-

hanjar-

jà6-

sa-

kàrày-
IPST

yá-

sā-

láam-

lágány-

nár-g-'

dáyn-

nási- ${ }^{2}$

cay- $^{2}$

car-

way-

sár-g-

págár-

láany-

sál-

hánjár-

ja6-

sá-

karan-

${ }^{1}$ The extra /g/ found in some IPSTs is not explainable at this point.

${ }^{2}$ The bases for the IPST seem to be nasiy- and cay-, respectively; cf. the respective verbal nouns nási and cày (or even càay?). 
(W2) The $\Lambda / \Lambda$ class

\begin{tabular}{|c|c|c|}
\hline 'to breathe' & $h \grave{\Lambda}-$ & $\mathrm{h} \Lambda-\mathrm{g}-$ \\
\hline 'to bite' & hǹd- & $h \Lambda d-$ \\
\hline 'to taste' & gìs- & $\mathrm{g} \Lambda \mathrm{s}-$ \\
\hline 'to yawn' & $\mathrm{h} \Lambda \mathrm{m}-$ & hím- \\
\hline 'to arrive' & gìr- & $\mathrm{g} \Lambda \mathrm{r}-\mathrm{g}-$ \\
\hline 'to walk' & $1 \wedge \mathrm{\eta}-$ & lín- \\
\hline 'to pass' & $\mathrm{p} \Lambda \mathrm{t}-$ & p $\Lambda ́ t-$ \\
\hline 'to greet' & w $\Lambda \mathrm{y}-$ & wńy- \\
\hline 'to send' & gìy- & g $\Lambda \mathrm{y}-$ \\
\hline 'to offend' & $\mathrm{h} \Lambda \mathrm{r}-$ & hńr-g- \\
\hline 'to heat' & ' $\Lambda \mathrm{l-}$ & ’ńl- \\
\hline 'to pound' & 'ìg- & ' $\Lambda \mathrm{g}-$ \\
\hline 'to grow' & $\mathrm{g} \grave{\Lambda} w-$ & 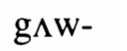 \\
\hline 'to untie' & $\mathrm{k} \Lambda \mathrm{r}-$ & kńr- \\
\hline 'to cover' & $h \wedge 6-$ & hи́6-6- \\
\hline 'to age' & wìn- & wAn- \\
\hline 'to be heavy' & $\mathrm{n} \Lambda^{-}$ & n $\Lambda ́-$ \\
\hline 'to pass the day' & $' \wedge 1 \wedge \mathrm{m}-$ & ' $\Lambda$ lńm- \\
\hline
\end{tabular}

(W3) The $\partial / \partial$ class

'to germinate'

6วn-

6án-

'to spit'

6әj-

báj-

'to descend'

jəb-

'to plait (hair)'

ləm-

jə́b-g-

'to moisten'

hว̀ny-

lám-

həny-

(W4) The $i / i$ class

'to spit' (Bag.)

ti6-

tíb-6-

'to marry'

bìy-

biy-

'to forget'

nim-

ním-

'to accept'

yid-

yíd-

'to slap'

big-

bíg-

'to shave'

yir-

'to dry' ('wring out')

wid-

yír-

'to swell'

sìy-

wíd-é-

'to belch'

dìs-

siy-

dis- 
(W5) The ele class

'to drink'

'to tickle'

'to carry'

'to pull'

'to spin'

'to plant'

'to open'

(W6) The $u / u$ class

'to urinate'

'to sit'

'to swim'

'to creep'

'to hear'

'to sing'

'to whistle'

'to discuss'

'to ask'

'to search'

'to lose'

'to meet'

'to take'

'to give'

'to stab'

'to bend'

'to burn'

'to sew'

'to pierce'

'to dig'

'to attach'

'to decay'

'to blow'

'to measure'

'to resemble' sè-

ked-

'è-

yè-

tedər-

dew-

teny-

wùj-

wuyny-

buj-

wur-

'ur-

kùy-

wuy-

wug-

hùr-

nyun-

'ud-ə

gubi-

ug-

hu-

bug-

dun-

kuy-

sur- ${ }^{4}$

bug-

kuti-

kùn-

'us-

wuy-

gùsì-

wuni- se-

kéd-g-

'e-

ye-

tédə́r-

déw-

tény-

wuj-

wúyny-

búj-é- ${ }^{3}$

wúr-

'úr-

kuy-

wúy-

wúg-

hur-g-

nyún-

'úd-

gúbi-

úg-

hú

búg-

dún-

kúy-

sú-

búg-

kútí-

kun-

'ús-

wúy-

gusi-

wúní-

${ }^{3} \mathrm{Cf}$. the form of the verbal noun, bujjé.

${ }^{4}$ In light of the verbal noun form sú, $\mathrm{C}_{2}-r$ - may be a perfective formative morpheme. 
'to shine'

'to rub'

(W7) The o/o class

'to snore'

'to enter'

'to touch'

'to teach'

'to refuse'

'to lift'

'to bury'

'to dry' wuliny-

yud-

door-

sodi-

'òd-

doy-

'yoon-

bò-

mò-

wòy- wúlíny-

yúd-

dóor-

sódí-

'od-

dóy-

'yóon-g-

bo-

mo-

woy-

3.3.2. "Strong" verbs. There are three types of "strong" verbs to be distinguished in Gadang depending on the nature and kind of ablaut the verbs undergo:

- Qualitative ablaut $\left(\mathrm{V}_{1} \rightarrow \mathrm{V}_{2} ; \mathrm{V}_{1}-\mathrm{V}_{2} \rightarrow \mathrm{V}_{1}-\mathrm{V}_{3}\right)$

- Quantitative ablaut $\left(\mathrm{V}_{1} \rightarrow \mathrm{V}_{1} \mathrm{~V}_{1}\right)$

- Mixed or double ablaut $\left(\mathrm{V}_{1} \rightarrow \mathrm{V}_{2} \mathrm{~V}_{2}\right)$

- Quantitative consonantal ablaut: $\left(\mathrm{C}_{2} \rightarrow \mathrm{C}_{2} \mathrm{C}_{2}\right)$

3.3.2.1. Strong verbs with qualitative ablaut. The following verb classes may be distinguished with regard to the vowel patterning the verbs display:

PST $-i-/$ IPST $-a$ -

PST - - - / IPST $-a$ -
PST $-u$ - / IPST $-a$ -

PST $-\Lambda$ - / IPST $-a$ -

The apophonic scheme as displayed in these four verb classes is of a "classical" nature. High $(i, u)$ and central vowels $(\partial, \Lambda)$ in the perfective are in contrast with low $A(=/ a, e, o /)$ in the imperfective.

(S1) The $i / a$ class

'to lie down'; 'to kill'

hiy-

riny-

bìy-

'to break' wul-

wud- háy-

rány-

bay-

(S2) The $u / a$ class

'to vomit'

'to fart' 
'to defecate'

'to give birth'

'to dance'

'to push'

'to wash'

'to tear' wùr-

hùw-

kun-

sungur-

wus-

gùrùn- war-

haw-

kwán-

súngár-

wás-

guray-

In a few cases, the change from $-u$ - to $-a$ - has, so to say, not been "mastered" so that the ablaut scheme has remained incomplete, i.e., $-u$ - did not go to $-a$ - but only to -o-. The following verbs display this incomplete $u / A(u / o)$ ablaut pattern.

The $u / o$ subclass

'to eat (hard)'

'to feel, smell'

'to fuck'

'to cry, weep'

'to find'

'to chase'

'to stir'

'to hide'

'to dress'

(S3) The o/a class

'to jump'

'to see'

'to seize'

'to envelop'

'to show'

'to divide'

'to finish'

'to beat'

'to crush'

'to light'

'to shatter'

'to split'

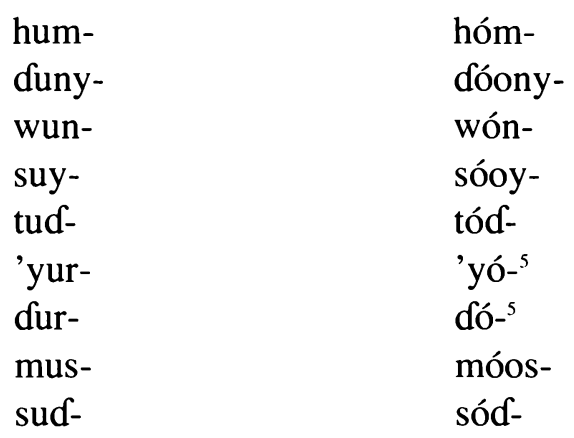

nว̀n-

nan-

gว̀l-

gal-

đวm-

ligər-

gər-

'วs-

nyəm-

6əl-

təs-

nyว̀m-

də̀s-

cว̀g- đám-

lígár-

gár-

'ás-

nyám-

bál-

tás-

nyam-

das-

cag-

\footnotetext{
${ }^{5}$ Compare the verbal noun forms of the two verbs, 'yóor and $d o$, respectively.
} 
'to cut'

'to till'

'to mix'

'to talk' jər-

yəg-

hawəny-

kə6- ja-

yág-

háwány-

ká6-6-

(S4) The $N / a$ class

'to fill'

${ }^{\prime} \Lambda \mathrm{n}-$
${ }^{\prime} \Lambda \mathrm{b} \Lambda \mathrm{r}-$

'án-

'to close'

’’̀b-b-ár-

3.3.2.2. "Strong" verbs with quantitative ablaut. Besides the dominant qualitative ablaut, there are a few verbs which display quantitative ablaut, either solely or in addition to the qualitative ablaut. Here is a short list of these verbs.

\subsection{Purely quantitative ablaut}

'to swallow'

'to cough'

'to come'

'to climb'

'to yell'

'to deceive'

'to help'

'to call' sar-

'as-

ha-

’àg-

'ar-

làm-

dày-

'̀̀r- sáar-

'áas-

háa-

'aag-

'áar-

laam-

daay-

' $\Lambda \Lambda \mathrm{r}-$

\subsection{Mixed quantitative/qualitative ablaut}

'to feel, smell'

'to hide'

'to die' duny-

mus-

mir- đóony-

móos-

méer- ${ }^{6}$

3.3.2.2.3. Quantitative consonantal ablaut, i.e., gemination of $\mathrm{C}_{2}$

'to talk'

'to accompany'

'to cover' kə6-

mar-

$\mathrm{h} \Lambda 6-$ ká66-

márr-

hí66-

${ }^{6}$ The vowel quality of -ee- tends to the open variety, $-\varepsilon \varepsilon-$, a quality which otherwise does not seem to be part of the Gadang phonemic vowel inventory. 
'to spit' (Bag.)

'to close' ti6-

' $\mathrm{b} \Delta \Lambda \mathrm{r}-$ tí66-

’ńbbár-

The latter example displays three formative features of a Gadang imperfective stem, i.e., (1) qualitative ablaut (of $\mathrm{V}_{2}$ ), (2) quantitative consonantal ablaut or gemination (of $\mathrm{C}_{2}$ ), and (3) a mid to high change of tone. Iconically, consonant gemination and vowel lengthening (= quantitative ablaut) are only two facets of the same underlying concept, both serving the purpose of marking imperfectivity.

\section{Conclusion}

Gadang has a verbal system that is still characterized by a basically sound apophonic structural mechanism, although it is already quite on the retreat considering the fact that more than half of our verbs are no longer ablautsensitive. This may be compared to Sibine (Sumray) the ablaut system of which is even less distinctive and functional (cf. Jungraithmayr 1978b). Gadang occupies a position between Sibine and Sokoro (Jungraithmayr n.d.), e.g., which still operates a more complex ablaut system. Geographically, Gadang is also situated between Sibine and Sokoro as seen in the following sketch.

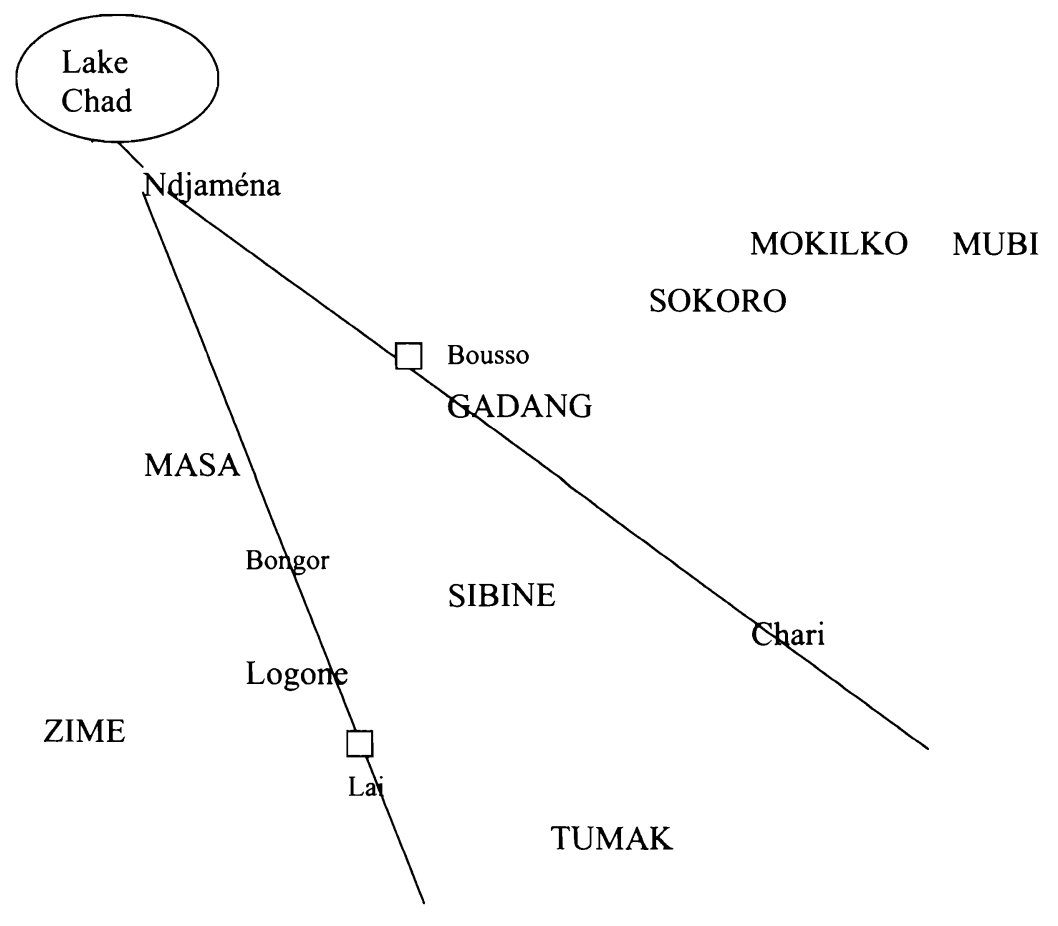




\section{REFERENCES}

Caprile, Jean-Pierre. 1975. Lexique tumak-français. Berlin: Dietrich Reimer. Ganslmayr, Herbert, and Herrmann Jungraithmayr (eds.). 1977. Gedenkschrift Gustav Nachtigal 1874-1974. Bremen.

Gaudefroy-Demombynes, M. 1907. "Documents sur les langues de l'Oubangui-

Chari." In Actes du $14^{e}$ congrès international des orientalistes. Paris.

Jungraithmayr, Herrmann. 1978a. "Ablaut und Ton im Verbalsystem des Mubi." Afrika und Übersee 61: 312-320

. 1978b. "Présentation d'un conte en sibine (sumray) - texte, notes et vocabulaire." In Cinq textes tchadiques (Cameroun et Tchad), ed. by $\mathrm{H}$. Jungraithmayr and J.-P. Caprile, pp. 177-211. Berlin: Dietrich Reimer.

. 1980. "Kontakte zwischen Adamawa-Ubangi- und Tschad-Sprachen: Zur Übertragung grammatischer Systeme." Zeitschrift der Deutschen Morgenländischen Gesellschaft 130: 70-85.

. 1990. Lexique mokilko. Berlin: Dietrich Reimer.

.1997. "Ablaut im Verbalsystem osttschadischer Sprachen." In Humanism,

Culture and Language in the Near East, ed. by A. Afsaruddin and A. H. Mathias Zahniser, pp. 345-353. Winona Lake, Indiana.

.n.d. "Notes sur le système verbal du sokoro". Ms.

Nachtigal, Gustav. 1879-1889. Sahara und Sudan, vols. I-III. Berlin-Leipzig (Reprint: Graz 1967).

Schuh, Russell G. 1976. The Chadic Verbal System and its Afroasiatic Nature. Malibu: Undena. (= Afroasiatic Linguistics 3(1):1-14.)

Herrmann Jungraithmayr

Frankfurt University

email: jungraithmayr@em.uni-frankfurt.de 